\title{
CONCEPT OF THE MOSQUE AS AN EDUCATION MEANS \\ FAITH AND THE END OF CHILDREN IN THE MODERN ERA
}

\author{
Nurhadi \\ Islamic High School (STAI) Al-Azhar Pekanbaru \\ Email: alhadijurnal@gmail.com
}

\begin{abstract}
Mosque in Islam selian for ubudiyah, also functions as a means of non-formal education for the Islamic community. In order for the mosque to function properly in Islamic law. So it needs an applicative and simple theory, according to the author, so that mosques can become educational facilities for children, it needs to be arranged in a systematic and directed manner, namely: 1). Looking for prospective husband and wife at the mosque. 2). Ta' aruf at the mosque. 3). Marriage contract at the mosque. 4). Pregnancy Children always go to the mosque. 5). Born Son in Azankan like Azan at the Mosque. 6). Since toddlers and children always learn Koran at the mosque. 7). Since Children and Mumayiz always pray at the mosque. 8). After Baligh Teach Stay at the Mosque. 9). After Adult, look for a diligent soul mate to the mosque. If the nine points above are implemented, then mosques will naturally become a mecca for the education of Islamic children. So the purpose of education is to make insane kamil who are devoted and have moral character.
\end{abstract}

Keywords: Concepts, Mosque, Education, Moral Faith, Children.

\begin{abstract}
Abstrak
Di era modern ini, masjid sangat megah dan mewah sebagai bentuk pengembangan peradaban Islam. Tidak hanya untuk ubudiyah, masjid adalah salab satu fasilitas pendidikan non-formal untuk komunitas Islam. Agar masjid berfungsi dengan baike dalam bukum Islam. Sebingga perlu teori yang aplikatif dan sederhana, menurut penulis, agar masjid dapat menjadi fasilitas pendidikan bagi anak-anak, perlu diatur secara sistematis dan terarah, yaitu: 1). Mencari calon suami-istri di masjid. 2). Ta'aruf di masjid. 3). Kontrak pernikahan di masjid. 4). Kehamilan Anak-anak selalu pergi ke masjid. 5). Anak Labir di Azankan seperti Azan di Masjid. 6). Karena balita dan anak-anak selalu belajar Alquran di masjid. 7). Karena Anak-anak dan Mumayiz selalu berdoa di masjid. 8). Setelah Baligh Mengajar Menginap di Masjï.
\end{abstract}

Nazhruna: Jurnal Pendidikan Islam

Vol. 2 No 2 2019. Issn: 2614-8013. Hal. 190-208

DOI: https://doi.org/10.31538/ nzh.v2i2.333 
9). Setelah Dewasa, cari jodoh yang rajin ke masjid. Jika sembilan poin di atas diterapkan, maka masjï secara alami akan menjadi kiblat bagi pendidikan anakanak Islam. Jadi tujuan pendidikan adalab untuk membuat kamil gila yang mengabdi dan memiliki karakter moral.

Kata kunci: Konsep, Masjid, Pendidikan, Iman Moral, Anak-anak.

\section{INTRODUCTION}

The house of God called a mosque in this era is mostly a place of worship. The global function of the mosque is not only a place of worship (prayer) but also as a referee perfecting knowledge, faith, charity and piety. Taqwa according to the concept of Islam is the highest predicate, because he is an accumulation of faith, Islam and ihsan. This shows that the mosque as a place for servants to express their faith in Allah Almighty, to worship Him and to act in His name. ${ }^{2}$

Even though the mosque is intended not only to function as a place of worship, especially prayer with all its settings. ${ }^{3}$ However, mosques also function as social facilities - such as education, study and other social activities and also function politically, namely as the center of government, the administration of the state and the place where various political consultations take place. ${ }^{4}$

Historical facts in Islam in the early days of the mosque as the main educational institution. This is what the Messenger of Allah did at the Nabawi mosque. In the mosque the Prophet educated Muslims of all ages and sexes; adults, teens, children, both men and women. For adults, they use the mosque to study the Koran, hadith, fiqh, the basics of religion, language and Arabic literature. ${ }^{5}$ While for women, they study the Koran, hadith, the basics of Islam and the skill of weaving or spinning, with a frequency of once a week. While children study in the porch of the mosque with Quranic

\footnotetext{
${ }^{1}$ YunaharIlyas, KuliahAkblak, (Yogyakarta: Institute for the Study and Practicing of Islam, 2012), p. 18-20.

${ }^{2}$ Darodjat and Wahyudiana, Functioning Mosques as Educational Centers for Forming Islamic Civilization, (Islamadina Journal, Volume XIII, No. 2, July 2014), 1-13, p. 1 accessed June 13, 2019 at 10:00

${ }^{3}$ Ali al-Jumbulati and Abdul Futuh at-Tuwaanisi, Comparison of Islamic Education, (Jakarta: RinekaCipta, 2012), p. 22.

${ }^{4}$ Encyclopedia of Islamic Law, Encyclopedia of Islamic Law, Jakarta: PT. Ikhtiar Baru, 2012), p. 1119-1122

${ }^{5}$ RizqunHanifMuhtarom, Utilization of the Mosque as a Center for Non-Formal Islamic Education, (Muhamadiyah University Surakarta, Surakarta, 2012), p. 5.
} 
material, religion, Arabic, counting, riding skills, archery and swimming. ${ }^{6}$ Therefore the mosque should function again as the center of civilization, but in reality what is now only as a place of prayer only, or at most only as a place to learn part of the science of religion. ${ }^{7}$

Speaking of Islamic education and education, we must see the function of the mosque. It has been proven in history that the mosque was the birth of an Islamic State. From the mosque, the leaders of the people were born. Why is that? Because in the mosque education is carried out for the Islamic community. We see how the Prophet first began the mental and physical education of his followers. He starts at the mosque. From the mosque he prepared strong Muslim cadres, only then did he establish an Islamic State based in Medina. ${ }^{8}$

One of the problems is that not all mosques can function properly. In fact, most mosques only carry out one of their functions, namely as a place of worship. That alone is not maximal. 'The many mosques that can be witnessed today are in a damaged condition, slum, quiet from visitors and languishing, which indicates the absence of proper and good management. ${ }^{10}$ While the mosque looks stylish and is quite crowded with people during prayer times, there are no other activities. There is also a side to prayer also for recitation activities or madrasah diniyah, but stop there. So the mosque is very rare with complete activities, both for the education of faith and its implementation in various activities. ${ }^{11}$

If mosques do not function properly, it is certainly difficult to expect the implementation of Islamic teachings properly. This requires the responsibility of Islamic leaders, including their scholars, how the mosque can function properly. One way that might be taken to empower mosques is by publishing success stories of mosques that are already good at managing education, da'wah and implementation of Islamic teachings in various aspects

${ }^{6}$ Abdullah Idi and Toto Sukarto, Revitalization of Islamic Education, (Yogyakarta: Tiara Wacana, 2015), p. 80-81

${ }^{7}$ Darodjat and Wahyudiana, Enabling Masji, p. 1

${ }^{8}$ Muhammad Quraish Shihab, Qur'anic Insights, (Bandung: Mizan, 2010), p. 461-462 61.

${ }^{9}$ MujamilQomar, Dimension of Islamic Education Management (Jakarta: Emir, 2015), p.

${ }^{10}$ Darodjat and Wahyudiana, Enabling Masji, p.4

${ }^{11}$ Darodjat and Wahyudiana, Enabling Masji, p.4 
so that they can be known and copied by other mosques, so that more mosques will function as it should be. ${ }^{12}$

Tens of thousands of mosques in Indonesia, even millions, of the many mosques that function well as centers of education and da'wah as well as the implementation of several Islamic teachings are the Al-Huda mosque located at RT 04 RW 03 in Tambaksogra village, Sumbang sub-district, Banyumas district. In the mosque education and da'wah activities appear more prominent than other mosques in Banyumas. This can be seen from several things, for example the number of jama'ah who pray five times always in large numbers, routine recitation goes well, TPA / TPQ activities are managed neatly. Have a medical center, library, TPQ / TPA building that is representative, and do not forget there are adequate bathrooms and toilets. Every Qurban day sacrifices large quantities of sacrificial animals so that people receive an abundant amount of qurban meat, zakat maal goes well, every moment of Islamic holidays is always filled with various Islamic activities such as tabligh akbar, carnival, mass circumcision etc. ${ }^{13}$

According to the theory of Islamic education, education requires an educational environment to achieve educational goals. ${ }^{14}$ There are three main educational environments, namely family, school, and society. Mosque is one of the non-formal educational facilities for the Islamic community. ${ }^{15}$ The existence of the mosque as one of the centers of Muslim community activities in Pedan District is at least able to provide its own color, one of them in the field of Islamic education. ${ }^{16}$ The main function of the mosque is a place for worship, besides that the mosque also functions as a place of education for all ages. ${ }^{17}$

${ }^{12}$ Wage, Functioning the Mosque as a Place for Islamic Education, (Journal of Islamidina Volume 19, No. 2, September 2018), 27-40, p. 28 accessed on June 14, 2019 at 10.10

${ }^{13}$ Wage, Functioning the Mosque as a Place of Islamic Education, p. 29

${ }^{14}$ Imam Nasruddin, Masjid; Islamic Education institution (A Study according to Islamic Education), (South Sumatra: Ministry of Religion, t.th), p. 1 accessed June 15, 2019 at 13.10

${ }^{15}$ Abd.Rahman Abdullah, Actualization of the Basic Concepts of Islamic Education, (Yogyakarta: UII Press, 2001), p. 77-78.

${ }^{16} \mathrm{NafisLuthfatulJanah,} \mathrm{The} \mathrm{Role} \mathrm{of} \mathrm{the} \mathrm{Mosque} \mathrm{as} \mathrm{an} \mathrm{Institution} \mathrm{for} \mathrm{Non-Formal} \mathrm{Islamic}$ Education for the Muslim Pedan Community (Study in Al-Jalal Mosque Gatak, Kedungan, Pedan, Klaten in 2016), (Islamic Education Faculty of Islamic Studies, Muhammadiyah University Surakarta, 2016), p. . 1 accessed June 14, 2019 at 11.00

${ }^{17}$ Haidar Putra Daulay, History of Growth and Renewal of Islamic Education in Indonesia, (Jakarta: KencanaPerdana Media Group, 2009), p. 20-21 
One of the successes of Islamic education and da'wah needs to be studied, to find out the secrets of success behind them. In language, a mosque means a place of prostration. ${ }^{18}$ The word sujud, according to several verses of the Koran which the author collects, contains several meanings, first, acknowledgment and respect to other parties such as the prostration of an Angel to Adam. ${ }^{19}$ Second, awareness of self-oversight and recognition of the truth of other parties such as the prostration of the magicians of the king Pharaoh after the prophet Moses showed miracles and defeated their magic. ${ }^{20}$ Third, prostration means following and adapting to God's provisions / sunnatullah such as prostration of animals, plants and so on. ${ }^{21}$ Some of the definitions above if related to the function of the mosque, namely the place of prostration, then it can be understood that the purpose of the word prostration is in the broadest sense. Prostration is an activity to acknowledge the majesty of God, honor Him, confession of one's own mistakes and to His Holiness from error, and prostration also means a statement of submission to all the rules of Allah swt. ${ }^{22}$

If you look at most mosques in this country, there will be a lot of irony that can be seen. Many mosques look magnificent but are quiet from activity. The doors are always locked and sometimes even look haunted. ${ }^{23} \mathrm{With}$ that the author believes that one way to create a place of Islamic education, the role of the mosque must have activities that can attract congregation in that place. ${ }^{24}$

${ }^{18}$ Cyril Glase, Ensiklopedi Islam, (Jakarta: Raja Grafindo, 2012), p. 262-263

${ }^{19}$ Please look in the Qur'an Surah Al-Baqarah (2): 30: Meaning: "Remember when Allah Almighty said to the Angels: "Verily Allah Almighty wants to create a caliph on the earth." The angel said: "Why does Allah want to make (people / caliphs) on earth those who will make mischief on earth and shed blood, whereas we angels always glorify and ordain and purify you?" Allah says: "Surely I know more about what you do not know". Ministry of Religion of the Republic of Indonesia, Al-Qur'an and Translation, (Semarang: Toha Putra, 2015), p. 12

${ }^{20}$ Please look in the Qur'an Thaha (20): 20: Meaning: Then he threw the stick, Then suddenly he became a snake that crawled quickly. Ministry of Religion, Al-Qur'an, p. 478

${ }^{21}$ Please look in the Qur'an Ar-Rahman (55): 55: Meaning: Which of your blessings do you deny? Ministry of Religion, Al-Qur'an, p. 889

${ }^{22}$ Wage, Functioning the Mosque as a Place of Islamic Education, p. 29

${ }^{23}$ AdiHermawan, The Role of the Mosque as a Center for Islamic Education and the Establishment of manners (Morals) in Adolescents (at Al-MubajirinSemanggi Mosque, PasarKliwon Surakarta), (Faculty of Islamic Studies, Muhammadiyah University Surakarta, 2012), p. 4 accessed June 13, 2019 at 11:30

${ }^{24}$ AdiHermawan, The Role of the Mosque, p. 4 
As the Prophet pointed out, during the Prophet's time the Prophet's Mosque in Medina had described its function so that the role of the mosque was very diverse and numerous. History records no fewer than ten roles that have been carried out by the Nabawi mosque, namely as a place of prayer, a place of discussion of religious knowledge and stay in touch (economic, social and cultural), an educational place, social compensation, military training and preparation of equipment, also a place to care for the mujahid who were injured in the war, places reconcile from disputes between people, guest meeting halls. ${ }^{25}$

\section{DISCUSSION}

\section{Terminology of the Mosque.}

The word "mosque" when viewed in the Qur'an is repeated twentyeight (28) times. The origin of the word "mosque" from the mustaq fi'il tsulatsi is sajada-yasjudu, which means obedient, obedient, and submissive with respect and takzhim (raising). ${ }^{26}$ Laying the forehead, both hands and knees, and the two ends of the feet to the earth, which is then worshiped by the shari'at, is the clearest outward form of meaning above. That is why the building is devoted to performing mosque prayer, which means a place to prostrate. $^{27}$

According to the daily understanding, it is the building of Muslim prayer rooms. But, because the root contains the meaning of submission and obedience. Therefore, the main function of a mosque is as a place to do all activities that contain an element of obedience to Allah alone. As in the Qur'an, Allah says (Surah Al-Jin, verse 18) is as follows: "Actually the mosques belong to Allah, therefore do not worship other than Allah". ${ }^{28}$ In a Hadith, the Messenger of Allah said: "It has been made for me (and for my people) the earth as a mosque and a means of purification. (Hadist History of Imam Bukhari and Muslim). ${ }^{29}$

If connected with the existence of this earth, the mosque is not only a place of prostration (prayer) and means of purification of the heart, tayamum

${ }^{25}$ AdiHermawan, The Role of the Mosque, p. 4

${ }^{26}$ Muhammad QuraishShihab, Al-Qur'an Insight. (Bandung: Mizan, 2016), p. 460

${ }^{27}$ A. Suherman, Masjid As an Institute for the Development of Religious Life for Youth, (t.tp: t.p, t.th), p. 7 accessed June 23, 2019 at 14.30

${ }^{28}$ Ministry of Religion, Al-Qur'an, p. 985

${ }^{29}$ Imam Bukhari, SabibBukhari. (Bairut: DarulIbnKathir al-Yammah, t.th). see also Imam Muslim, Shabih Muslim (Beirut: Dar Kutub, t.th). 
and wudlu, but the meaning of the mosque is also a place to perform human activities that reflect obedience and obedience to God Almighty. Thus, the mosque becomes "The base of the place of departure, as well as the port of anchorage". ${ }^{30}$

\section{History of Mosques in Islam.}

The Qur'an calls the word "Masjid" 18 times and the word "Bait" which refers to "Masjid al-Haram" is called 17 times. Another word that indicates the meaning of the mosque is "Maqam Ibrahim" and "Mushalla", each of which is called 1 time. Whereas in the Prophetic traditions, dozens of hadiths were found which discussed the mosque, its virtues and the laws surrounding the mosque, all of which showed the importance of the position of the mosque in Islam.. ${ }^{31}$

When the Messenger of Allah emigrated from Mecca to Medina, the first step was to build a small mosque called the Quba Mosque '. ${ }^{32}$ When built this mosque was grounded, and roofed with palm fronds. From this small mosque, then the Prophet built a great Islamic civilization. The rapid development of the city of Medina itself began with the construction of a mosque. ${ }^{33}$

It is very clear that the existence of the mosque requires an element of devotion. The establishment of each mosque should be done on the basis of devotion, not on the basis of grandeur. Even in a saheeh hadith narrated by Imam Ahmad and IbnHibban from Anas bin Malik it is stated that, one of the signs of the end of the world is the construction of various mosques but with the intention of making a splendor. ${ }^{34}$

The mosque is baitullah (house of God), as well as baitul jamaah, a home for Muslims, because from the beginning, the mosque has been able to become the glue that unites Muslims, regardless of their background. In

${ }^{30}$ A. Suherman, Masjid As a Development Institution, p. 8

${ }^{31}$ R. Taufiqurrochman, Mosque-Based Community Education, (Department of Arabic Language Education, State Islamic University Maulana Malik Ibrahim Malang, t.th), p. 3 accessed June 22, 2019 at 14.40

${ }^{32}$ Imam Nasruddin, Masjid; Islamic Education institution, p. 2. See also Ade Hermawan, The Role of the Mosque as a Center in Islamic Education and the Establishment of Youth Literature, (Muhammadiyah University Surakarta, Surakarta, 2012), p. 4.

${ }^{33} \mathrm{Abdullah}$ Idi and Toto Sukarto, Revitalizing Islamic Education, p. 80

${ }^{34}$ Imam Jalal al-Din al-Suythi, Al-Jami 'al-Saghir, Ahmad Dasuki's translation (Bandung: Al Maarif, t.th.), Juz II, p. 202 
history, even though a mosque was built by the government, organizations, institutions, groups and individuals, the reality is that the position of the mosque until now remains as a common property, which belongs to Muslims who each has the same rights and obligations to glorify the mosque. This is actually the privilege of a mosque that is not owned by other institutions such as madrasas, educational institutions, state palaces, museums, libraries and so on. ${ }^{35}$

From the beginning, the mosque remained independent (mustaqillah) whose organization and management also remained based on the congregation (community). The management or takmir of the mosque is chosen and agreed upon by the community in their own way. In addition, Takmir's decision always sided with the mosque (read: the interests of the wider community), even though the mosque did not have a constitution or written rules. This democracy-style democratization is the fruit of its status as "waqaf" (belonging to Allah) which means shared property. With its status as waqaf, mosques can consistently carry out their roles "from, by and for the Ummah" and as a place of worship for the purposes of ritual worship, studying, uniting vision and mission, etc.. ${ }^{36}$

\section{The Global Function of Mosques according to Islam.}

At the time of the Prophet the mosque functioned for various activities, meaning its function was universal, including a gathering place for Muslims and the Messenger of Allah to learn the laws and foundations of the religion of Islam. ${ }^{37}$ MenurytSuryadharma Ali stated that at that time the mosque was a place for; 1) worship (prayer); 2) education and teaching center; 3) justice center; 4) community economic empowerment center; 5) information center; 6) military and government training centers. ${ }^{38}$

According to Ramayuli, such a function is not only for the Apostle era, but also in the following period, namely the golden age of Islam,

\footnotetext{
${ }^{35}$ Mu'nis, et al. Al-Masajid.Tsaqafiyah Pole Lineage (t.tp: t.p, 1990), p. 1 accessed June 21, 2019 at 3:30 p.m.

${ }^{36}$ R. Taufiqurrochman, Mosque Based Community Education, p. 4 2009), p. 24

${ }^{37}$ Ali Al-Jumbulati, et al., Comparison of Islamic Education, (Jakarta: PT. Rineka Cipta,

${ }^{38}$ Suryadharma Ali, Islamic Boarding School Paradigm: Extending the Horizon of Study and Action, (Malang: UIN Maliki Press, 2014). See also Wage, Functioning the Mosque as a Place of Islamic Education, p. 30
} 
especially for the large mosque. ${ }^{39}$ According to Abdeh, function of the mosque as happened in the era of the Prophet was a universal function that should continue to be maintained, namely a mosque as a place of worship, a place of culture and education, a public service area for health and social benefits. $^{40}$

In the Encyclopedia of Islamic Law it is stated that ancient mosques functioned for social activities such as da'wah, education, and political functions, namely as a center of government, state administration and various political consultations. ${ }^{41}$ According to Shihab, even now a large mosque should function like that. For this reason, he suggested that in building mosques equipped with various facilities to function properly and have an attraction for all people. ${ }^{42}$

When discussing the function of the mosque, Quraish Shihab referred to Q.S. an-Nur [24] verses 36-37, which essentially means that the function of the mosque is to celebrate. ${ }^{43}$ But prayer beads here are not only in the sense of saying the word "subhanallah", but more broadly, namely taqwa. ${ }^{44}$ So in general the function of the mosque is to carry out taqwa, in which the meaning of taqwa is "to guard oneself from the torment of Allah, by carrying out all His commands with obedience and avoiding all His prohibitions in the form of immorality and evil". ${ }^{45}$ In the concept of Islam, taqwa itself is the highest predicate, because it is an accumulation of faith, Islam and ihsan. ${ }^{46}$

${ }^{39}$ Ramayulis, History of Islamic Education: Napaktilas Changes in the Concept, Philosophy and Methodology of Islamic Education from the Age of the Prophet to the Ulama Nusantara, Jakarta: KalamMulia, 2012), p. 18-19

${ }^{40}$ Damas Addeh and Sayida Fuad, Legal Legality of Mosque Construction and Muslim Religious Affairs in Egypt: Towards Strengthening State control. (t.tp: t.p, 2011)., p. 1 accessed June 21, 2019 at 20.30

${ }^{41}$ Encyclopedia of Islamic Law, Encyclopedia of Islamic Law, Jakarta: PT. Ikhtiar Baru, 2011), p. 1120

${ }^{42}$ Muhammad QuraishShihab, Al-Qur'an Insight, p. 463

${ }^{43}$ Look in the Qur'an Surah an-Nur [24] verses 36-37: Meaning: 36. So glorify Allah Almighty in the mosques that have been ordered to be glorified and called His name in them, in the morning and evening; 37. A man who is not neglected by commerce and buying and selling from the remembrance of Allah, and establishes prayer, and pays zakat. they are afraid one day, when the heart and vision will be lost.. Ministry of Religion, the Qur'an, p. 550

${ }^{44}$ Muhammad QuraishShihab, Al-Qur'an Insight, p. 461. See also Darodjat and Wahyudiana, Enabling Masji, p. 6.

${ }^{45}$ Ahmad Umar Hasyim, Being a Muslim Kafah, (Yogyakarta: MitraPustaka, 2015), p. 618

${ }^{46}$ Yunahar Ilyas, KuliahAkblak, p. 18-20 


\section{Mosque for Children's Education Facilities.}

According to Al -didi quoted from Iskandar and Akhmad Mujab explained that the mosque is the best place for educational activities. Therefore educational institutions in mosques will see the life of the Sunnahs of Islam, uphold the laws of God and the disappearance of racial stratification and economic status in education. ${ }^{47}$ Thus, the mosque is the second institution after the family in educating children. ${ }^{48}$ Mosques are important institutions in the process of institutionalizing Islamic education in children. According to J Pederson and George Maksidi cited by Arief Subhan, the mosque which was carried out by the assembly with Al-Qur'an learning as its main material was the center of learning and education that emerged the earliest in Islam. ${ }^{49}$

Educational goals according to Zuhairini argue that: "The general goal of Islamic education is to guide children to become true Muslims, believers, steadfast, virtuous charity, and noble and useful for society, religion and the state". ${ }^{50}$

The moral formation activities in the mosque are supported by the existence of mosque management and youth forums which are wellestablished and supported by the surrounding community including conducting regular Islamic education studies, holding express boarding schools and also conducting Qur'anic guidance. The activities of adolescent mosques as the younger generation of Muslim heirs to the mosque's da'wah should have attitudes and forms of actions that are always based on Islamic values whose movements seem to be in a cycle of believing, knowledgeable, pious charity and having an attitude of ma'rufnahimunkar. ${ }^{51}$

If you look at Islamic history about children's rights to mosques, then the writer remembers the message of Sultan Muhammad Al-Fatih

${ }^{47}$ Akhmad Mujab, Mosque Management as a Center for Islamic Education in the Tradition of the Tabligh Jamaah Da'wah in Al - Jihad Seturan Mosque Yogyakarta (State Islamic University Yogyakarta, 2018, page 2 accessed June 25, 2019 hours 20.30

${ }^{48}$ Iskandar You, History of Islamic Education, (Bandung: PT. Teenagers Rosda Karya, 2014), p. 112. 5

${ }^{49}$ Arief Subhan, 20th Century Indonesian Islamic Education Institute, Jakarta: Kencana, 2012), p. 37

${ }^{50}$ Zuhairini, Philosophy of Islamic Education, (Jakarta: Bumi Aksara, 1995), p. 51.

${ }^{51}$ Ade Hermawan, Important role of the mosque as a Center for Islamic Education in the Formation of Adolescent Law, (Muhammadiyah University Surakarta, Surakarta, 2012), p. 4. 
(Conqueror of Constantinople): "If at some time in the future you will no longer hear the noise and laughter of children cheerfully between shaf- Shaf prayer in the mosques, then really fear you for the fall of your young generation at that time ". O my brother / i. Please pay attention to mosques in your area, silent or still married with chatter and jokes typical of children or already alienated from the mosque solemnly in front of TV Games and Gadgets. Never forbid children to go to the mosque for reasons of noise and disturb "kekhusyuan" prayers. Because when they disappear their small voices are typical in our mosques. That is the Sign of the Collapse and Fall of the Next Generation. While children in mosque are innocent angels. So if the child is always oriented to the mosque, this indicates that the children will appear willingly.

\section{Mosque Structured Mechanism for Children's Education Facilities. Looking for prospective husband and wife at the mosque.}

Prospective husbands will be enthusiastic and feel light to pray in congregation in the mosque, even competing to arrive at the beginning of time, before the prayer begins, and never late (unless there is udzur syar'i). In the hadith, it is stated that among the hallmarks of hypocrites, men are reluctant to establish prayers, and are lazy to come to prayer in congregation in mosques, especially morning and evening prayers. As for women, it is better to pray at home and not be stressed to pray at the mosque, even if there are a lot of slander and harm to the mosque. But women are also not prohibited from praying at the mosque. This means that the prospective wife who is good is the one who diligently goes to the mosque. Do not marry a man who likes to wake up late, if he wakes up in the morning for morning prayers he cannot, how can he build a household. In the hadith it is mentioned that people who have good faith are the ones who lightly step into the mosque. Also the hadith about dating a mate or marrying a good religion. So people who are diligent in mosques are good people of religion.

\section{Ta'aruf at the mosque.}

If the desire to find a partner is to those who are diligent in the mosque, ta'arufan will automatically occur within the mosque in a way that is justified in Islam, whether through his parents who bring him to the mosque or to his mahram as a matchmaker. The mosque is one of the best and right ta'aruf houses, because people in the mosque will always get the blessings and 
blessings of Allah because the mosque is the home of Allah SWT. Also ta'aruf including pious charity towards marriage, about this Allah has touched it indirectly in surah Al-Nahl verse 97 meaning: "Whoever does righteous deeds (ta'aruf), both men and women in the State of faith (intention to get married), Then Allah will surely give him a better life (sakinah family) and surely Allah will give them a better gift than anything they have done". ${ }^{2} \mathrm{Ta}$ 'aruf is one way to get to know each other between men and women who have the desire to build a household with marriage. ${ }^{53}$

\section{Marriage contract at the mosque.}

Look for prospective life partners in the mosque, ta'aruf in the mosque, most likely the marriage contract will be carried out in the mosque. The majority of scholars recommend marriage contracts in mosques to get baraka, and be known to the public. ${ }^{54}$ Based on the hadith of the Prophet: Announce marriage, and do it in the mosque, and (enliven) by hitting duf (tambourine) (HR. Tirmizi, Baihaqi). ${ }^{55}$ The foundation of recommendations from other hadiths about a woman who offered herself to marry the Prophet, then she married her to one of her friends in the mosque (HR. Bukhari Muslim) ${ }^{56}$ In another hadith mentioned the best place is the mosque, the most loved by Allah in a country is the mosque, so without exception the best place for marriage contract is a mosque. The mosque is also the quietest place, it is expected that the marriage contract in the mosque will bring peace in the household (samawa).

\section{Pregnancy Children always go to the mosque.}

Almost certainly if someone is looking for a mate, a life partner, both husband and wife who are diligent in the mosque, God willing, usually in the

\footnotetext{
${ }^{52}$ Ministry of Religion, Al-Qur'an, p. 417

${ }^{53}$ Reni Nurmwati, Islamic Law Review of the Ta'aruf Process in the Establishment of Sakinah Family at Ta'aruf House Taman Sorga Binaan Ustadz. Awan Abdullah, (State Islamic University Sunan Kalijaga Yogyakarta, 2017), p. ii

${ }^{54}$ Wizarah al-Awqaf wa al-Shu'un al-Islamiyah bi al-Kuwait, al-Mausu'ah al-Fiqhiyah, (Kuwait: Wizarah al-Awqaf al-Kuwaitiyyah, t.th), Juz 37, p. 214.

${ }^{55}$ Imam Tarmizi, Al-Sunan Al-Tirmizi. (Lebanon: Dar al-Hadith, t.th). see also Imam Baihaqi, Sunan al-Kubra, sunan al-Baibaqi. (Lebanon: MaktabahWakfiyah, t.th).

${ }^{56}$ Imam Bukhari, Abu Abdullah Muhammad ibn Ismail Al-Bukhari bin Ibrahim bin Al-Mughirah bin Bardizbah, SabibBukhari. (Bairut: DarulIbnKathir al-Yammah, t.th). see also Muslim Imam, AbulHusayn Muslim ibn al-Hajjaj bin Muslim ibnKausyaz al Qusyairi an Naisaburi, Shahih Muslim (Beirut: Dar Kutub, t.th).
} 
mosque and of course the marriage contract in the mosque, after being blessed with pregnancy will almost certainly not go to the mosque, because to the mosque is no longer compulsion but needs that have become a habit. If this is done by the mother of the children she is carrying out, then the child in the womb will always understand and memorize the way to the mosque following the steps of her mother, this is the candidate born to the child who is blessed to pray for his parents.

\section{Born Son in Azankan like Azan at the Mosque.}

The usually the mother of children in the womb to the mosque is to grant the call to prayer. For example, if the child is born, he will not miss the call to prayer that he has been listening to all this time, and will also be heard to his newborn child. Because the call of God that is often heard by most people is the call to prayer at five times of prayer time. The person who fulfills the call to prayer for prayer is the person in his heart who also has sentences of the call to prayer. Therefore it has become appropriate for parents who expect their children to be pious and blessing to keep their newborn child or mengiqomahkanya, both boys and girls, as the hadith of the Prophet: "I saw the Prophet Muhammad raising his voice when he prayed in the ear of Al-Hasan bin Ali when Fatima gave birth to him". (Narrated by Abu Daud, TirmidziBaihaqi).${ }^{57}$ By playing the call to prayer, the child is expected to absorb it to the heart of the heart, it is desirable that when the big later like to respond and grant the call to prayer to bow down to Allah swt. This includes the first Tawhid education in Islam.

\section{Since toddlers and children always learn Koran at the mosque.}

The term learning is not a big wait, but rather from toddlers (toddlers) until the grave. So it is always a good idea for parents to always bring their toddlers and children to the mosque, introducing a noble and noblest place, the house of the creator of Allah Almighty. In the mosque it means, both for prayer and learning the Koran recitation. Based on the history of the Holy Prophet that he said: " If people gather in one of God's houses (the mosque) while reading the Qur'an and asking each other

\footnotetext{
${ }^{57}$ Imam Abu Daud, Shabih Sunan Abu Daud. (Lebanon: Dar al-Hadith, t.th), Hadith 5105, Imam Tarmizi, Al-Sunan Al-Tirmizi. (Lebanon: Dar al-Hadith, t.th). hadith 1514. Imam Baihaqi, Sunan al-Kubra, sunan al-Baihaqi. (Lebanon: Maktabah Wakfiyah, t.th), hadith 300.
} 
together, surely peace will come upon them, the mercy of Allah will cover them, the angels will protect them and Allah calls them to beings who are by His side "(Narrated by Muslim) ${ }^{58}$ In another hadith: "Indeed (mosques) are only for (place) zikrullah, salat, and qira'ah Al-Qur'an" (Narrated by Muslim).${ }^{59}$ According to the hadith above, it is appropriate for children to learn the Koran in the mosque. ${ }^{60}$

\section{Since Children and Mumayiz always pray at the mosque.}

The age of children is the age of gold, so take advantage of it as a parent to always take care of it and maintain it like a precious gold piece, by always being invited to the mosque to pray and learn to interact with the surrounding community (hospitality). Indeed the Prophet Muhammad always interacted with the Children at the Prayer in the Mosque. The following is a story that can be used as a lesson for us, which is handled by Rosululloh peace be upon him, narrated by a friend of the Prophet named Yaddad ra: One time the Prophet came to the mosque to perform prayers and the Prophet brought his grandson, Hasan and Hussein, then the Prophet put his grandson on beside him, then the Prophet lifted Takbirotul ihrom started the prayer, in the Prophet's salutation, his prostration was very long not as usual, so I quietly lifted my head to see what was happening, and sure enough, I saw the Prophet's grandson Riding the Back of the Prophet who was Prostrate, After Seeing the Event I Returned Prostration with the Other Makmum, When Finished Prayers The Friends were busy Asking at Rosululloh: "O Rosululloh, Your Majesty Sujud very long, So that We Had thought something had happened or Your Majesty was receive Revelation ". Your Majesty Rosul answered: "No, no, nothing happened, but only my grandson climbed my body, and I did not want to hunt until he finished playing with himself. (HR. Nasa'i and Hakim). ${ }^{61}$ If Muslim Children Run, Cheerful, Laughing at the Mosque is the Characteristics of Children, Remind Them with Sweet Hugs and Smiles, Actually They are "Angels" who are

${ }^{58}$ Imam Muslim, Shabih Muslim, (Beirut: Dar Kutub, t.th). hadis 2699. See also Abu Anas Ali ibn Husayn Abu Luz, Bida'u An-Naasi Fii Al-Qur'an, (Indonesian Edition of Deviations Against the Qur'an, Translator Ahmad Amin Sjihab, (Penerbit Darul Haq), hadith. 100, 1998

${ }^{59}$ Imam Muslim, Shabih Muslim, hadith, 100, 1998

${ }^{60}$ Abdullah Idi and Toto Sukarto, Revitalizing Islamic Education, p. 80-81

${ }^{61}$ Imam Nasa'i, Al-Sunan al-Nasa'i. (Cairo: Dar Ilmi, t.th). see also Imam Hakim, Mustadrak ala Shahahain Imam Hakim, (Lebanon: Maktabah ilmiyah, t.th), hadith 1041 
Rejoicing at His Robb House, in another History the Prophet Speeded His Prayer because there was a cry of a small child who called his mother who was taking part in prayer praying together with the Messenger of Allah, that was the Prophet's mosque that was not empty of small children, so it was worthy that the mosque administrators were given an understanding of mosques as centers of Islamic civilization.

\section{After Baligh taught to stay at the mosque.}

The desire of parents for their children to be good children is the ideal of all people, if early education since toddlers, children and then mumayiz to baligh or adults are always taught to go to the mosque, recite, study and pray, God willing with their own children our adolescents will get used to and adhere to their hearts always to the mosque, even living and sleeping in mosques as done by teenagers in ancient times, this is in accordance with the philosophy and motto of the Minangkabau people: "girls guard the house of surau guard boys", it means to recite, study, pray and even sleep in a mosque (mosque). If a teenager always adheres to the mosque, then he can be called a pious young man, in the hadith mentioned a young man who always engraved his heart to the mosque then he will get the shade of Allah on the Day of Judgment that there is no shade except the shade of Allah (HR. Bukhari Muslim). ${ }^{6}$ This is a real picture of pious children and sholehah that should be in every family.

\section{After Adult, look for a diligent soul mate to the mosque.}

The discussion about this matter has been explained by the author at the beginning of this sub-chapter, that a good prospective husband or wife is a diligent one who goes to the mosque, both in prayer and prayer. His habit of going to the mosque from an early age will always inspire him to look for a life partner who diligently goes to the mosque so that his soul and emotions are both to megabdi to Allah SWT. So the marriage between the two servants who are always dependent and adrift to the mosque is a marriage of worship, as is usual worship both do in the mosque, except that it does not include mahdhah worship but gharu mahdhah. Nevertheless marriage is half of

${ }^{62}$ Imam Bukhari, Sabih Bukhari. (Bairut: Darul Ibn Kathir al-Yammah, t.th). see also Ima Muslim, Shabih Muslim (Beirut: Dar Kutub, t.th). hadith 1031 
religion, imperfect one's religion, both male and female before marriage, because of that sunnatullah and sunnah of the Prophet.

\section{CONCLUSION}

In language, a mosque means a place of prostration. At that time the Prophet Muhammad made the Prophet's Mosque in Medina had outlined its function so that the role of a diverse mosque was born, indicating that the mosque had a very universal function, including as a place of education. Mosque as an institution for education for all ages and ages. The theory of Islamic education strongly requires the existence of an educational environment in order to achieve educational goals. There are three main educational environments, namely family, school, and society. Mosque is one of the non-formal educational facilities for the Islamic community. If mosques are always used as a mecca in society, the aim of Islamic education will be to give birth to a generation that is pious, ta'at and berakhlakuk karimah will be realized. But that will not happen just like that, it requires applicative and exspriment theory, according to the author, so that mosques can become srana Islamic education for children, so an applicative and simple theory is needed, according to the author, so that mosques can become educational facilities for children children, need to be structured systematically and structured, namely: 1). Looking for prospective husband and wife at the mosque. 2). Ta'aruf at the mosque. 3). Marriage contract at the mosque. 4). Pregnancy Children always go to the mosque. 5). Born Son in Azankan like Azan at the Mosque. 6). Since toddlers and children always learn Koran at the mosque. 7). Since Children and Mumayiz always pray at the mosque. 8). After Baligh Teach Stay at the Mosque. 9). After Adult, look for a diligent soul mate to the mosque. If the nine points above are implemented, then mosques will naturally become a mecca for the education of Islamic children. So the purpose of education is to make insane kamil who are devoted and have moral character. 


\section{REFERENCES}

Abdullah, Abd. Rahman, Actualization of the Basic Concepts of Islamic Education. Yogyakarta: UII Press, 2001.

Abu Luz, Abu Anas Ali bin Husain, Bida'u An-NaasiFii Al-Qur'an. Indonesian Edition of Deviations Against the Qur'an, Translator Ahmad Amin Sjihab. DarulHaq Publisher.

Addeh, Damas and SayidaFuad, The Legal Framework of Mosque Building and

Muslim Religious Affairs in Egypt: Towards a Strengthening of State control. t.tp: t.p, 2011. accessed June 21, 2019 at 20.30

Ali, Suryadharma, Islamic Boarding School Paradigm: Extending the Horizon of Study and Action. Malang: UIN Maliki Press, 2014.

Al-Jumbulati, Ali and Abdul Futuh at-Tuwaanisi, Comparison of Islamic Education. Jakarta: RinekaCipta, 2012.

Al-Jumbulati, Ali, et al., Comparison of Islamic Education. Jakarta: PT. RinekaCipta, 2009.

Al-Suyŭti, Jalal al-Din, Al-Jami 'al-Saghir. Bandung: Al Maarif, t.th. Juz II

Darodjat, and Wahyudiana, Functioning Mosques as Educational Centers for Forming Islamic Civilization.Islamadina Journal, Volume XIII, No. 2, July 2014., 1-13, accessed June 13, 2019 at 10:00

Daulay, Haidar Putra, History of Growth and Renewal of Islamic Education in Indonesia. Jakarta: KencanaPerdana Media Group, 2009.

RI Ministry of Religion, Al-Qur'an and Translation. Semarang: Toha Putra, 2015.

Ministry of Religion of the Republic of Indonesia, the Qur'an and its Translation. Jakarta: Ministry of Religion, 1990.

Engku, Iskandar, History of Islamic Education. Bandung: PT.RemajaRosdakarya, 2014.

Encyclopedia of Islamic Law, Encyclopedia of Islamic Law. Jakarta: PT IchtiarBaru Van Hoeve, 2010.

Encyclopedia of Islamic Law, Encyclopedia of Islamic Law. Jakarta: PT IchtiarBaru Van Hoeve, 2001.

Glase, Cyril, Encyclopedia of Islam. Jakarta: PT Raja GrafindoPersada, 2012.

Hasyim, Ahmad Umar, Becomes a Muslim Kafah. Yogyakarta: MitraPustaka, 2015.

Hermawan, Adi, The Role of Mosques as Centers for Islamic Education in the Formation of Adolescent Morals (at Al-MubajirinSemanggi Mosque, 
PasarKliwon Surakarta). The Faculty of Islamic Studies, Muhammadiyah University Surakarta, 2012., accessed June 13, 2019 at 11:30

Idi, Abdullah and Sukarto, Toto, Revitalizing Islamic Education. Yogyakarta: Tiara Wacana, 2015.

Ilyas, Yunahar, KuliabAkblak. Yogyakarta: Institute for the Study and Practicing of Islam, 2012.

Imam Abu Daud, Sulaimanibn al-Ash'atsibnIshaqibnBisyribnSyaddadibn 'Amribn' Imran, Abu Dawud al-Azdi as-Sijistani, ShabihSunan Abu Daud. Lebanon: Dar al-Hadith, t.th.

Imam Baihaqi, Abu Bakr Ahmad ibn Al-Husaynibn Ali ibn Musa AlKhusrauijrdi Al-Khurasani Al-Baihaqi, Sunan al-Kubra, sunan alBaihaqi. Lebanon: MaktabahWakfiyah, t.th.

Imam Bukhari, Abu Abdullah Muhammad ibn Ismail Al-Bukhari bin Ibrahim bin Al-Mughirah bin Bardizbah, SabibBukbari.Bairut: DarulIbnKathir al-Yammah, t.th.

Imam Hakim, Abu Abdillah Al-hakim Muhammad bin Abdullah bin Muhammad bin Na'im bin Al-hakamAdh-dhabbiAth-Athahmani AnNasaiburi, MustadrakalaShahahain Imam Hakim. Lebanon: Maktabahilmiyah, t.th.

Muslim Imam, AbulHusayn Muslim ibn al-Hajjaj bin Muslim ibnKausyaz al QusyairianNaisaburi, Shahih Muslim. Beirut: Dar Kutub, t.th.

Imam Nasa'i, Abu 'Abdirrahmanahmad bin su'aib bin ali bin bahr bin sinan bin dinar an-Nasai al-Kurasani., Al-Sunan al-Nasa'i. Cairo: Dar Ilmi, t.th.

Imam Nasruddin, Masjid; Islamic Education institution (A Study according to Islamic Education). South Sumatra: Ministry of Religion, t., Accessed June 15, 2019 at 13.10

Imam Tarmizi, Abu 'Isa Muhammad bin a isa bin surrah al-Turmudzilbn Musa IbnAdh-Dhahak Al-Sulami Al-Bughi Al-Tirmidhi, Al-Sunan AlTirmizi. Lebanon: Dar al-Hadith, t.th.

Janah, NafisLuthfatul, The Role of the Mosque as an Institution for Non-Formal Islamic Education for the Pedan Muslim Community (Study in Al-Jalal Mosque Gatak, Kedungan, Pedan, Klaten in 2016). The Islamic Religion Education Study Program at the Faculty of Islam, Muhammadiyah University Surakarta, 2016., accessed June 14, 2019 at 11.00 
Langgulung, Hasan. Islamic Education in the 21st Century. Jakarta: alHusnaZikra, 2001.

Mu'nis, et al. Al-Masajid.Tsaqafiyah Pole Lineage.t.p: t.p, 1990., accessed June 21, 2019 at 3:30 p.m.

Muhtarom, RizqunHanif, Utilization of the Mosque as a Center for Non-Formal Islamic Education. Muhamadiyah University Surakarta, Surakarta, 2012.

Mujab, Akhmad, Mosque Management as a Center for Islamic Education in the Tradition of the TablighJamaabDa'wah in Al-Jihad Mosque in Seturan Yogyakarta. The Islamic Education Management Study Program at the Faculty of Tarbiyah and Teacher Training at the State Islamic University of SunanKalijaga Yogyakarta, 2018.accessed June 25, 2019 at 20.30

Nurmwati, Reni, Islamic Law Review of the Ta'aruf Process in the Establishment of a Sakinah Family at the Ta'aruf House of the SorgaBinaan Park UstadzAwan Abdullah. Faculty of Sharia and Law UIN SunanKalijaga Yogyakarta, 2017.accessed June 25, 2019 at 9:30 p.m.

Qomar, Mujamil, Dimension of Islamic Education Management. Jakarta: Emir, 2015.

Ramayulis, History of Islamic Education: Napaktilas Changes in the Concept, Pbilosophy and Methodology of Islamic Education from the Age of the Prophet SAW to the Archipelago Ulama. Jakarta: KalamMulia, 2012.

Shihab, Muhammad Quraish, Al-Qur'an Insight. Bandung: Mizan, 2016.

Shihab, Muhammad Quraish, Al-Quran Insight. Bandung: Mizan, 2010.

Subhan, Arief, 20th Century Indonesian Islamic Education Institute. Jakarta: Kencana, 2012.

Suherman, A., Masjid As an Institute for the Development of Religious Life for Youth. t.tp: t.p, t.th., accessed June 23, 2019 at 14.30

Taufiqurrochman, R., Mosque-Based Community Education. Department of Arabic Language Education Faculty of Science and Teacher Training of State Islamic University (UIN) Maulana Malik Ibrahim Malang, t., Accessed June 22, 2019 at 14.40

Wage, Functioning the Mosque as a Place of Islamic Education. Journal of Islamidina Volume 19, No. 2, September 2018., 27-40, accessed June 14, 2019 at 10.10 .

Wizarah al-Awqafwa al-Shu'un al-Islamiyah bi al-Kuwait, al-Mausu'ab alFiqhiyah. Kuwait: Wizarah al-Awqaf al-Kuwaitiyyah, t.th.,Juz 37

Zuhairini, Philosophy of Islamic Education. Jakarta: BumiAksara, 1995. 